УДК: 352/354: 658.8

https://doi.org/10.32689/2618-0065-2020-3(5)-49-59

Божкова Вікторія Вікторівна доктор економічних наук, професор, професор кафедри бізнес-економіки та адміністрування Сумського державного університету імені А.С. Макаренка, вул. Роменська, 87, м. Суми, Сумська обл., 40002 Україна, тел.: +38 (0542) 68-59-10, e-mail: vvbozhkova@gmail.com, https://orcid.org/0000-0002-1557-3819

Линник Сергій Олександрович доктор наук з державного управління, доцент, професор кафедри бізнес-економіки та адміністрування Сумського державного університету імені А.С. Макаренка, вул. Роменська, 87, м. Суми, Сумська обл., 40002 Україна, тел.: +38 (0542) 68-59-10, e-mail: econom@sspu.edu.ua, https://orcid.org/0000-0002-6405-3123

\title{
ПУБЛІЧНЕ УПРАВЛІННЯ ТА АДМІНІСТРУВАННЯ ТЕРИТОРІЙ: МАРКЕТИНГОВИЙ АСПЕКТ
}

Анотація. У статті, на основі аналізу вітчизняної законодавчої бази, наукових праць та досвіду з поширених практик діяльності регіональних органів управління окреслено проблему недостатньої уваги органів державної влади і місцевого самоврядування до впровадження концепції маркетингу територій. Визначено особливі характеристики маркетингу територій як філософії територіального розвитку з використанням сучасного інструментарію. Окреслено суб'єктів просування територій, до яких віднесено: центральні органи державної влади; органи місцевого самоврядування і місцеві державні адміністрації; громадських і публічних діячів (національних й іноземних), посадових осіб міжнародних організацій, політиків, діячів науки і освіти, культури і мистецтва; суб'єктів економічної діяльності всіх видів і галузей (підприємства, установи і організації, центральні офіси i представництва корпорацій, холдингів, туристичні оператори i агентства, заклади сфери гостинності (готелі, заклади харчування, розваг), торговельні мережі тощо); представників інфраструктури бізнесу і ринку (територіальні економічні асоціації розвитку, торгові доми, підприємства транспорту, зв'язку, ЗМІ, фінансові установи тощо); громадські організації і осередки політичних партій; спортивні клуби, комітети і федерації; заклади освіти; діаспору; інших.

Запропоновано визначати три рівні впровадження заходів маркетингу територій, а саме: макрорівень - рівень центральних органів державної влади; мезорівень - рівень органів місцевого самоврядування і місцевих державних адміністрацій; мікрорівень - рівень окремих суб'єктів господарювання. Це, на відміну від існуючих підходів дозволяє розмежовувати повноваження між суб'єктами маркетингу територій. 
Окреслено окремі види заходів та виконавців, відповідно запропонованих рівнів управління.

Ключові слова: публічне управління та адміністрування, маркетинг територій, просування, суб'єкти, рівні управління.

Bozhkova Viktoriya Viktorivna, Doctor of Economics, Professor of Business-Economics and Administration Department, Sumy Anton Makarenko State Pedagogical University, street Romenska, 87, Sumy, Sumy region, 40002 Ukraine, tel: +38 (0542) 68-59-10, e-mail: vvbozhkova@gmail.com, https://orcid.org/0000-0002-1557-3819

Lynnyk Serhiy Oleksandrovych Doctor of Public Administration, Professor of Business-Economics and Administration Department,Sumy Anton Makarenko State Pedagogical University, street Romenska, 87, Sumy, Sumy region, 40002 Ukraine, tel: +38 (0542) 68-59-10, e-mail: econom@sspu.edu.ua, https://orcid.org/0000-0002-6405-3123

\section{PUBLIC MANAGEMENT AND ADMINISTRATION OF TERRITORIES: MARKETING ASPECT}

Abstract. In the article, based on the analysis of the national legislative framework, scientific works, and experience on common practices of the activities of regional authorities, the problem of insufficient attention on the part of state authorities and local self-government to introduce the concept of territorial marketing is outlined. The specific characteristics of territorial marketing as a philosophy of territorial development using modern tools have been identified. The subjects of promotion of the territories to which are referred to are: central government bodies; local self-government bodies and local state administrations; public and public figures (national and foreign), officials of international organizations, politicians, scientists and educations, culture and the arts; subjects of economic activity of all kinds and industries (enterprises, institutions, and organizations, head offices and representative offices of corporations, holdings, tourist operators and agencies, hospitality establishments (hotels, catering establishments, entertainments), trade networks, etc.); representatives of business and market infrastructure (territorial economic development associations, trading houses, transport enterprises, communications, mass media, financial institutions, etc.); non-governmental organizations, and branches of political parties; sports clubs, committees, and federations; educational institutions; diaspora; others.

It is proposed to define three levels of implementation of territorial marketing measures, namely: macro level - the level of central state authorities; mezzanine the level of local self-government bodies and local state administrations; microlevel - the level of individual business entities; this, unlike existing approaches, allows you to differentiate between entities marketing territories. Some types of 
activities and performers are outlined, according to the proposed levels of management.

Keywords: public management and administration, territory marketing, promotions, entities, levels.

Постановка проблеми. Реформування територіальної організації влади та місцевого самоврядування, яке розпочалось в Україні з 2014 р. [1] 3 ратифікації Європейської хартії місцевого самоврядування [2] на засадах урахування у державній політиці інтересів жителів територіальних громад, актуалізувало проблеми децентралізації влади, перерозподілу функцій і повноважень між центральними і місцевими органами управління, посилення фінансової самостійності останніх тощо. Але, на наш погляд, недостатньо окресленими і опрацьованими залишаються питання впровадження концепції маркетингу територій на різних рівнях управління, які є особливо важливими для розвитку територіальних громад в умовах глобалізації світової економіки.

У Концепції реформування місцевого самоврядування та територіальної організації влади в Україні [1]чітко визначені напрями, механізми і строки формування ефективного місцевого самоврядування та територіальної організації влади для створення i підтримки повноцінного життєвого середовища для громадян, надання високоякісних та доступних публічних послуг, становлення інститутів прямого народовладдя, задоволення інтересів громадян в усіх сферах життєдіяльності на відповідній території, узгодження інтересів держави та територіальних громад. Але, аналіз узагальненого переліку розподілу повноважень між органами місцевого самоврядування та органами виконавчої влади свідчить, що немає жодного положення щодо маркетингових заходів, які у сучасному світі набувають першочергового значення. Це стосується і Закону України «Про засади державної регіональної політики» [3].

У розділі «Цілі державної регіональної політики до 2020 року» Державної стратегії регіонального розвитку на період до 2020 року було зазначено, що для України метою № 1» $\epsilon$ підвищення рівня конкурентоспроможності регіонів: сприяння організації та проведенню форумів, зустрічей представників ділових кіл, презентацій, виставковоярмаркових заходів, засідань за круглим столом тощо [4]. Цих заходів не достатньо для комплексного просування територій i їх перелік має бути розширеним, але важливим вже був сам факт їх констатації і розуміння важливості.

Наприкінці 2019 р. Міністерство розвитку громад та територій, розуміючи відсутність механізму практичної реалізації Державної стратегії регіонального розвитку, а також, єдиного підходу щодо розроблення та реалізації стратегічних документів на місцевому рівні, розробило законопроект про удосконалення регіональної державної політики [5]. На виконання Указу Президента України від 20 вересня 2019 р. № 713 (що за указ, посилання) та відповідно до Закону України «Про засади державної 
регіональної політики» зацікавленими органами здійснюється підготовка проекту Державної стратегії регіонального розвитку на 2021-2027 роки. Відповідно до основних світових тенденцій запропоновано нову модель регіональної політики, яка має відмінності від політики минулих періодів і у якій передбачено таке [6]:

фокус державної підтримки на проблемні території та точки зростання; об'єктами політики стають не лише адміністративно-територіальні одиниці, а й функціональні території;

державні інвестиції спрямовуються не лише на створення об'єктів «твердої» інфраструктури, а й на м'які розвиткові проекти на основі якісної діагностики потенціалів та проблем регіонів та різних типів функціональних територій;

реалізація державних програм та проектів здійснюється із обов'язковим урахуванням документів просторового планування (генеральна схема, схеми планування регіонів, схеми планування громад).

Зміщення фокусу державної політики в бік проблем територій $є$ важливим, але механізми їх розвитку та просування залишаються не розробленими.

Отже, недосконалість наявної законодавчої бази та механізмів підтримки розвитку територій у нових умовах господарювання окреслюють для науковців комплекс завдань щодо конкретизації заходів 3 впровадження концепції маркетингу територій та визначення сфер відповідальностей для їх реалізації. На другому етапі проведення реформи 3 децентралізації влади в Україні в рамках удосконалення механізму координації діяльності центральних і місцевих органів виконавчої влади необхідно, на наш погляд, конкретизувати заходи щодо просування територій на різних рівнях управління.

Аналіз останніх досліджень і публікацій. Науковці-маркетологи, які розглядають маркетинг територій як окремий вид маркетингу, достатньо широко дослідили його особливості. Авторами грунтовних наукових праць 3 цієї тематики є Котлер Ф. [7], Ромат Є. [8], Старостіна А.О. і Мартов С.С. [9], Панкрухин А.П. [10], Бондаренко В.М. і Шершун К.О. [11], Дудкіна О. [12], Смерічевський С.Ф. і Сібрук В.Л. [13], Трегубов О.С. [14], Гринкевич С., Брух О., Бернацька I. [15] та інші.

Зокрема, Бондаренко В.М. і Шершун К.О. присвятили своє дослідження узагальненню зарубіжних та вітчизняних підходів до розуміння територіального маркетингу, а також, питанням використання маркетингових інструментів у стратегічному розвитку регіонів та визначення можливостей ïx використання в Україні [11]; Дудкіна О.- організаційно-функціональним і методичним аспектам маркетингу територій, як управлінської технології, що застосовується органами державної виконавчої влади та органами місцевого самоврядування в сфері забезпечення конкурентоспроможного розвитку регіону [12]; Смерічевський С.Ф. і Сібрук В.Л. - пошуку і обгрунтуванню сучасних інструментів маркетингу територій, спрямованих на оптимізацію 
проведення маркетингових досліджень адміністративно-територіальних одиниць [13].

Але, особливості просування територій 3 використання специфічних сучасних маркетингових заходів на різних рівнях публічного управління $\mathrm{i}$ адміністрування, на наш погляд, не достатньо висвітлені і потребують подальшого поглибленого обгрунтування.

Метою статті $\epsilon$ дослідження особливостей впровадження концепції маркетингу територій органами державної влади і місцевого самоврядування. Відповідно до мети окреслено комплекс наступних завдань:

визначити суб’єктів просування територій;

визначити рівні впровадження маркетингових заходів;

окреслити види заходів маркетингу територій;

визначити виконавців за окремими видами маркетингової діяльності.

Виклад основного матеріалу. За визначенням науковців маркетинг території - це вид маркетингу; діяльність 3 використання комплексу спеціалізованих інструментів для ефективного просування території, iіi назви i можливостей серед фактичних i потенційних споживачів в інтересах населення і господарюючих суб'єктів цієї території.

3 визначенням Гринкевич С., Брух О. та Бернацької I. у системі управління соціально-економічним розвитком регіонів виокремлюють традиційні підходи до маркетингу територій, а саме як [15]:

1) засобу розширення присутності в регіоні суб'єктів економічної діяльності та нарощування передусім економічного потенціалу;

2) способу диверсифікації регіональної економіки, удосконалення іiі структури через підтримку інноваційних видів економічної та іншої діяльності, освоєння нових ринкових ніш, пошук і залучення інвестиційних ресурсів;

3) управлінського механізму, спрямованого на раціональне довготермінове управління розвитком території, створення іiі бренду на основі врахування конкурентних переваг, просування на ринки унікального регіонального продукту, адаптацію до кон'юнктурних коливань і зовнішніх впливів.

Отже, маркетинг територій є своєрідною філософією територіального розвитку з використанням сучасного інструментарію (у тому числі і в першу чергу - цифрових засобів комунікацій).

Кожна територія має свою історію, потенціал (можливості і ресурси), конкурентні переваги (у різних сферах господарювання), імідж тощо. Суб'єктами просування i так званого «продажу» території можуть бути зацікавлені структури, які мають проявляти комунікаційні активності 3 метою представлення іï інтересів та залучення уваги до неї можливих споживачів; в першу чергу, це:

центральні органи державної влади;

органи місцевого самоврядування і місцеві державні адміністрації; 
громадські і публічні діячі (національні й іноземні), посадові особи міжнародних організацій, політики, діячі науки i освіти, культури i мистецтва;

суб'єкти економічної діяльності всіх видів і галузей (підприємства, установи і організації, центральні офіси і представництва корпорацій, холдингів, туристичні оператори і агентства, заклади сфери гостинності (готелі, заклади харчування, розваг), торговельні мережі тощо);

представники інфраструктури бізнесу і ринку (територіальні економічні асоціації розвитку, торгові доми, підприємства транспорту, зв'язку, ЗМІ, фінансові установи тощо);

громадські організації і осередки політичних партій;

спортивні клуби, комітети і федерації;

заклади освіти;

діаспора;

інші.

Ймовірно, що завдяки застосуванню маркетингу території можливе підвищення рівня іiі економічного розвитку, рівня життя і добробуту іiі населення. Реалізація цієї концепції на загальнодержавному рівні дозволить розширити участь окремих територій у реалізації міжнародних і загальнонаціональних програм і в кінцевому сенсі - сприятиме розвитку національної економіки.

Одними з кращих суб’єктів для просування територій на міжнародному рівні, в першу чергу є суб'єкти, орієнтовані на зовнішньоекономічну діяльність. Вони не обов'язково мають бути розміщені на цій території. Наприклад, туристи, представники діаспори або трудові мігранти $є$ носіями і поширювачами унікальних вражень про територію на якій не проживають постійно.

Заходи 3 цільового просування територій мають здійснюватись системно, комплексно і послідовно. Отже, доцільним є розподіл повноважень між різними суб'єктами маркетингу територій і існує нагальна необхідність розмежування та конкретизації функцій між різними гілками влади та рівнями управління щодо їх реалізації.

Так, наприклад, Міністерство розвитку громад та територій України, яке $\epsilon$ головним органом у системі центральних органів виконавчої влади, що забезпечує формування та реалізує державну регіональну політику, державну політику у сфері розвитку місцевого самоврядування, територіальної організації влади та адміністративно-територіального устрою [16] логічно мало б очолити та впроваджувати діяльність 3 просування територій та їх привабливих сторін, стимулювання інтересів інвесторів, створення/ підтримки/ посилення позитивного іміджу територій, підвищення їх привабливості, конкурентоспроможності, престижу на міжнародному рівні.

Таблиия 1

Окремі завдання для суб'сктів маркетингу територій

\begin{tabular}{|l|l|l}
\hline Рівень & Завдання & Суб'єкти
\end{tabular}




\begin{tabular}{|c|c|c|}
\hline \multirow[t]{4}{*}{ Макрорівень } & Просування територій на міжнародному рівні & $\begin{array}{l}\text { Міністерство закордонних } \\
\text { справ України, } \\
\text { Міністерство розвитку } \\
\text { громад та територій } \\
\text { України }\end{array}$ \\
\hline & Участь територій у міжнародних проектах & $\begin{array}{l}\text { Міністерство розвитку } \\
\text { економіки, торгівлі та } \\
\text { сільського господарства } \\
\text { України }\end{array}$ \\
\hline & Залучення зовнішніх інвесторів & $\begin{array}{l}\text { Міністерство фінансів } \\
\text { України }\end{array}$ \\
\hline & $\begin{array}{l}\text { Проведення/участь у спортивних, культурних, } \\
\text { наукових заходах на міжнародному рівні }\end{array}$ & $\begin{array}{l}\text { Міністерство культури та } \\
\text { iнформаційної політики } \\
\text { України, Міністерство } \\
\text { освіти і науки України }\end{array}$ \\
\hline \multirow[t]{8}{*}{ Мезорівень } & $\begin{array}{l}\text { Проведення } \\
\text { досліджень }\end{array}$ спеціальних $\quad$ маркетингових & \multirow{8}{*}{$\begin{array}{l}\text { Органи місцевого } \\
\text { самоврядування і місцеві } \\
\text { державні адміністрації }\end{array}$} \\
\hline & Створення бренду території & \\
\hline & Обгрунтування стратегії розвитку території & \\
\hline & $\begin{array}{l}\text { Підтримка позитивного іміджу території на } \\
\text { місцевому, національному та міжнародному } \\
\text { рівнях }\end{array}$ & \\
\hline & Просування регіональних бізнес-проектів & \\
\hline & $\begin{array}{l}\text { Підвищення конкурентоспроможності } \\
\text { території }\end{array}$ & \\
\hline & $\begin{array}{l}\text { Підвищення привабливості зосереджених на } \\
\text { території природних, матеріально-технічних, } \\
\text { фінансових, трудових, організаційних, } \\
\text { соціальних та інших ресурсів }\end{array}$ & \\
\hline & \multirow{2}{*}{$\begin{array}{l}\text { Просування на ринках унікальних } \\
\text { регіональних продуктів }\end{array}$} & \\
\hline \multirow[t]{3}{*}{ Мікрорівень } & & \multirow{3}{*}{$\begin{array}{l}\text { Місцеві суб’єкти } \\
\text { господарювання }\end{array}$} \\
\hline & $\begin{array}{l}\text { Визначення та реалізація власних ключових } \\
\text { факторів успіху }\end{array}$ & \\
\hline & $\begin{array}{lccr}\text { Впровадження } & \text { власної } & \text { цільової стратегії } \\
\text { просування } & \text { власного } & \text { продукту } \\
\text { внутрішньому та зовнішніх } & \text { нинках } & \\
\end{array}$ & \\
\hline
\end{tabular}


Пропонуємо визначати такі рівні впровадження маркетингових заходів 3 просування територій:

макрорівень - рівень центральних органів державної влади;

мезорівень - рівень органів місцевого самоврядування і місцевих державних адміністрацій;

мікрорівень - рівень окремих суб'єктів господарювання.

Окреслимо коло повноважень і завдань для кожного з визначених рівнів (табл.1). Вони не є остаточними. Так, просування територій на міжнародному рівні і участь у міжнародних проектах є сферою спільних зусиль суб'єктів всіх рівнів

Кожен суб'єкт маркетингу територій традиційно самостійно здійснює вибір інструментів, повідомлень, каналів, засобів ефективних маркетингових комунікацій. Але досвід засвідчує, що ті громади й території, які поступово впроваджують взаємопов'язані маркетингові заходи, є більш успішними [17]. Отже, при реалізації зазначених у табл. 1 завдань доцільним є об’єднання зусиль суб'єктів різних рівнів управління.

На заваді цієї діяльності, на наш погляд, постають повільні процеси формування «інформаційного суспільства» (розвиток інформаційних комунікацій, інформаційної відкритості тощо - сфера компетенцій Міністерства цифрової трансформації України), недостатнє інфраструктурне забезпечення (сфера компетенцій Міністерства інфраструктури України) i т.і., а також, не достатнє розуміння важливості i, відповідно, не достатнє приділення уваги) впровадження концепції маркетингової діяльності у публічному управлінні та адмініструванні територій.

Висновки та перспективи подальших досліджень. За результатами проведеного дослідження отримані такі висновки:

1) визначення видів суб'єктів маркетингу територій дозволяє в подальшому формалізувати сфери і види відповідальностей у процесі просування територій;

2) визначено три рівні впровадження заходів маркетингу територій, а саме: макрорівень - рівень центральних органів державної влади; мезорівень - рівень органів місцевого самоврядування і місцевих державних адміністрацій; мікрорівень - рівень окремих господарюючих суб'єктів, що, на відміну від існуючих підходів дозволяє розмежовувати повноваження між суб'єктами маркетингу територій.

Результати даного дослідження можуть бути впровадженні в діяльність 3 просування територій органів державної влади, місцевого самоврядування, та окремих суб'єктів господарювання, а також покладені в основу подальших наукових розвідок.

Лimepamypa: 
1. Про схвалення Концепції реформування місцевого самоврядування та територіальної організації влади в Україні: розпорядження Кабінету Міністрів України від 1 квітня 2014 p. № 333-p. // База даних «Законодавство України» / ВР України. URL:https://zakon.rada.gov.ua/laws/show/333-2014-\%D1\%80 (дата звернення: 20.05.2020)2. Свропейська хартія місцевого самоврядування (м. Страсбург, 15 жовтня 1985 року).// База даних «Законодавство України» / BP України. URL: https://zakon.rada.gov.ua/laws/show/994_036 дата звернення: 20.05.2020)

3. Про засади державної регіональної політики: Закон України. від 5 лютого 2015 року № 156-VIII. // База даних «Законодавство України» / BP України. URL: https://zakon.rada.gov.ua/laws/show/156-19 (дата звернення: 20.05.2020)

4. Державна стратегія регіонального розвитку на період до 2020 року (із змінами): постанова Кабінету Міністрів України від 06.08.2014.(із змінами) // База даних «Законодавство України» / BP України. URL: https://zakon.rada.gov.ua/laws/show/385-2014\%D0\%BF/print1446542150663211 (дата звернення:20.05.2020)

5. У Кабміні розробили нову редакцію закону щодо стимулювання розвитку регіонів (26.11.2019 р.) / Веб-сайт RBC. URL: https://www.rbc.ua/ukr/news/kabminerazrabotali-novuyu-redaktsiyu-zakona-1574787744.html (дата звернення:20.05.2020)

6. Живицький Д. В основі проекту Державної стратегії регіонального розвитку до 2027 року знаходиться людина, іï потреби та можливості для розвитку. / Урядовий портал. URL: https://www.kmu.gov.ua/news/v-osnovi-proektu-derzhavnoyi-strategiyiregionalnogo-rozvitku-do-2027-roku-znahoditsya-lyudina-yiyi-potrebi-ta-mozhlivosti-dlyarozvitku-dmitro-zhivickij (дата звернення:20/0/2020).

7. Котлер Ф., Асплунд К., Рейн И. Маркетинг мест. Привлечение инвестиций, предприятий, жителей и туристов в города, коммуны, регионы и страны Европы. СПб.: Стокгольм. шк. экономики, 2005.377 с.

8. Ромат Є. До питання використання елементів маркетингу в державному управлінні. Вісник УАДУ. 2002. -№ 3. - С.33-37.

9. Старостіна А.О., Мартов С.С. Регіональний маркетинг: суть та особливості становлення в Україні. Маркетинг в Украӥні. -2004. № 3. С. 55-57.

10. Панкрухин А.П. Маркетинг территорий: 2-е изд., дополн. СПб.: Питер, 2006. $416 \mathrm{c}$.

11. Бондаренко В.М., Шершун К.О. Поняття та інструменти територіального маркетингу в контексті стратегічного розвитку регіонів. Науковий вісник Ужгородського університету : Серія: Економіка. Ужгород: Видавництво УжНУ «Говерла», 2012. Вип. 2 (36). С. 66-73.

12. Дудкіна О. Маркетинг територій як інструмент забезпечення конкурентоспроможного розвитку Регіональні аспекти розвитку $i$ розміщення $\begin{array}{llll}\text { продуктивних сил } & \text { Украӥни. } & \text { 2016. № } 21 .\end{array}$ URL: $\underline{\text { http://rarrpsu.tneu.edu.ua/index.php/rarrpsu/article/view/178/176 }}$ (дата звернення:20.05.2020)

13. Смерічевський С.Ф., Сібрук В.Л. Стратегічні аспекти маркетингу територій в умовах децентралізації управління України. Причорноморські економічні студії. Розвиток продуктивних сил і регіональна економіка. Випуск 26-2. 2018. С. 55-59.

14. Трегубов О.С Теоретичні аспекти маркетингу території. Вісник Хмельницького національного університету. 2010. № 6. Т. 4. С. 128-131.

15. Гринкевич С., Брух О., Бернацька I. Вплив маркетингового середовища на розвиток об'єднаних територіальних громад. Аграрна економіка. 2018.T. 11. № 1-2.

16. Положення про Міністерство розвитку громад та територій України: постанова Кабінету Міністрів України від 30 квітня 2014 р. № 197 в редакції постанови Кабінету Міністрів України від 25 вересня 2019 р. № 850. // Міністерство розвитку громад та територій України. URL: http://www.minregion.gov.ua/about/ (дата звернення: 20.05.2020). 
17. Кейс-стаді. Брендинг i маркетинг територій. Федерація канадських муніципалітетів. Проект міжнародної технічної допомоги «Партнерство для розвитку міст», 2019. Децентралізація. URL: https://decentralization.gov.ua/uploads/library/file/486/Regional_BrandingMarketing_2019.pdf (дата звернення: 20.05.2020).

\section{References:}

1. Pro skhvalennia Kontseptsii reformuvannia mistsevoho samovriaduvannia ta terytorialnoi orhanizatsii vlady v Ukraini [On approval of the Concept of reforming local selfgovernment and territorial organization of power in Ukraine. Order of the Cabinet of Ministers of Ukraine of April 1, 2014 № 333-r]. zakon.rada.gov.ua. Retrieved from https://zakon.rada.gov.ua/laws/show/333-2014-\%D1\%80 [in Ukrainian].

2. Ievropeiska khartiia mistsevoho samovriaduvannia. Strasburh, 15.10.1985. [European Charter of Local Self-Government. Strasburh, 15.10.1985]. zakon.rada.gov.ua. Retrieved from https://zakon.rada.gov.ua/laws/show/994_036 [in Ukrainian].

3. Zakon Ukrainy Pro zasady derzhavnoi rehionalnoi polityky vid 05.02.2015 № 156VIII [Law of Ukraine On the Principles of State Regional Policy of February 5, 2015 № 156VIII]. zakon.rada.gov.ua. Retrieved from https://zakon.rada.gov.ua/laws/show/156-19 [in Ukrainian].

4. Derzhavna stratehiia rehionalnoho rozvytku na period do 2020 roku (iz zminamy, vnesenymy zghidno z Postanovoiu KM № 1089 vid 20.12.2017) [State strategy of regional development for the period up to 2020 (as amended in accordance with the Resolution of the Cabinet of Ministers № 1089 of 20.12.2017)]. zakon.rada.gov.ua. Retrieved from https://zakon.rada.gov.ua/laws/show/385-2014-\%D0\%BF/print1446542150663211 [in Ukrainian].

5. U Kabmini rozrobyly novu redaktsiiu zakonu shchodo stymuliuvannia rozvytku rehioniv. 26.11.2019 r. [The Cabinet of Ministers has developed a new version of the law on stimulating the development of regions. November 26, 2019]. RBC.UA. Retrieved from https://www.rbc.ua/ukr/news/kabmine-razrabotali-novuyu-redaktsiyu-zakona-1574787744.html [in Ukrainian].

6. Zhyvytskyi, D. (2019) V osnovi proektu Derzhavnoi stratehii rehionalnoho rozvytku do 2027 roku znakhodytsia liudyna, yii potreby ta mozhlyvosti dlia rozvytku [The draft State Strategy for Regional Development until 2027 is based on people, their needs and opportunities for development]. kmu.gov.ua. Retrieved from https://www.kmu.gov.ua/news/v-osnovi-proektuderzhavnoyi-strategiyi-regionalnogo-rozvitku-do-2027-roku-znahoditsya-lyudina-yiyi-potrebita-mozhlivosti-dlya-rozvitku-dmitro-zhivickij [in Ukrainian].

7. Kotler, F. (2005). Marketynh mest. Pryvlechenye ynvestytsyi, predpryiatyi, zhytelei y turystov $v$ horoda, kommunbl, rehyonbl y stranbl Evropbl [Marketing places. Attracting investments, enterprises, residents and tourists to cities, communes, regions and European countries]. Saint Petersburg: Stokholm. shk. эkonomyky [in Russian].

8. Romat, Ye. (2002). Do pytannia vykorystannia elementiv marketynhu v derzhavnomu upravlinni [Prior to nutrition marketing to the sovereign government]. Visnyk UADU - UADU Bulletin, 3, 33-37 [in Ukrainian].

9. Starostina, A.O. \& Martov, S.Ie. (2004). Rehionalnyi marketynh: sut ta osoblyvosti stanovlennia v Ukraini [Regional marketing: the essence of the peculiarities of becoming in Ukraine]. Marketynh v Ukraini - Marketing in Ukraine, 3, 55-57 [in Ukrainian].

10. Pankrukhyn, A.P. (2006). Marketynh terrytoryi [Territory Marketing]. Saint Petersburg: Pyter [in Russian].

11. Bondarenko, V.M. \& Shershun, K.O. (2012). Poniattia ta instrumenty terytorialnoho marketynhu $\mathrm{v}$ konteksti stratehichnoho rozvytku rehioniv [Concepts and tools of 
territorial marketing in the context of strategic development of regions]. Naukovyi visnyk Uzhhorodskoho universytetu. Seriia: Ekonomika - Scientific Bulletin of Uzhgorod University: Series: Economics, 2 (36), 66-73 [in Ukrainian].

12. Dudkina, O. (2016). Marketynh terytorii yak instrument zabezpechennia konkurentospromozhnoho rozvytku [Marketing of territories as a tool to ensure competitive development]. Rehionalni aspekty rozvytku i rozmishchennia produktyvnykh syl Urainy Regional aspects of development and location of productive forces of Ukraine, 21. Retrieved from http://rarrpsu.tneu.edu.ua/index.php/rarrpsu/article/view/178/176 [in Ukrainian].

13. Smerichevskyi, S.F. \& Sibruk, V.L. (2018). Stratehichni aspekty marketynhu terytorii $\mathrm{v}$ umovakh detsentralizatsii upravlinnia Ukrainy [Strategic aspects of territory marketing in the conditions of decentralization of management of Ukraine]. Prychornomorski ekonomichni studii. Rozvytok produktyvnykh syl i rehionalna ekonomika - Black Sea Economic Studies. Development of productive forces and regional economy, 26-2, 55-59 [in Ukrainian].

14. Trehubov, O. S. (2010). Teoretychni aspekty marketynhu terytorii [Theoretical aspects of territory marketing]. Visnyk Khmelnytskoho natsionalnoho universytetu - Bulletin of Khmelnytsky National University, 6, 4, 128-131 [in Ukrainian].

15. Hrynkevych, S., Brukh, O. \& Bernatska, I. (2018). Vplyv marketynhovoho seredovyshcha na rozvytok obiednanykh terytorialnykh hromad. [The influence of the marketing environment on the development of united territorial communities]. Ahrarna ekonomika Agrarian economy, 11, 1-2 [in Ukrainian].

16. Polozhennia pro Ministerstvo rozvytku hromad ta terytorii Ukrainy (Postanova KMU vid 30 kvitnia 2014 r. № 197 v redaktsii postanovy KMU vid 25 veresnia 2019 r. № 850). [Regulations on the Ministry of Development of Communities and Territories of Ukraine (Resolution of the Cabinet of Ministers of April 30, 2014 № 197 as amended by the Resolution of the Cabinet of Ministers of September 25, 2019 № 850)]. minregion.gov.ua. Retrieved from http://www.minregion.gov.ua/about/ [in Ukrainian].

17. Keis-stadi. Brendynh i marketynh terytorii. Federatsiia kanadskykh munitsypalitetiv. Proekt mizhnarodnoi tekhnichnoi dopomohy «Partnerstvo dlia rozvytku mist» [Case study. Branding and marketing of territories. Federation of Canadian Municipalities. International Technical Assistance Project "Partnership for Urban Development"]. decentralization.gov.ua. Retrieved from https://decentralization.gov.ua/uploads/library/file/486/Regional_BrandingMarketing_2019.pdf [in Ukrainian]. 